\title{
ХАРАКТЕРИСТИКА ІСТОРИКО-ПСИХОЛОГІЧНОГО ПРОЦЕСУ В КОНТЕКСТІ ПЕРЕБІГУ «ВІДКРИТОЇ ПСИХОЛОГІЧНОЇ КРИЗИ»У ПОГЛЯДАХ С. Л. РУБІНШТЕЙНА
}

УдК: 159.9.019

\section{Ларін Дмитро Ігорович}

Аспірант кафедри загальної психології Київського начіонального університету імені Тараса Шевченка, м. Київ (Україна)

\begin{abstract}
Анотація. У даній статті подано характеристику історики-психологічного процесу в контексті періоду «відкритої психологічної кризи» згідно концептуального підходу видатного вченого, Рубінштейна Сергія Леонідовича. Описано методологічні принципи та їх значення для історико-психологічної науки, окреслено проблематику розвитку психологічних шкіл першої третини ХХ століття.

Особливу увагу автор звертає на формування поведінкової психологї - рефлексологї та біхевіоризму. Всі проблеми теорї та історії психології зосереджуються С. Л. Рубінштейном в єдиному вчинковому принцииі, за допомогою якого вирішується иентральна проблема психологї проблема людини.
\end{abstract}

Ключові слова: історико-психологічний прочес, «відкрита психологічна криза», методологія, принципи, теорії, біхевіоризм, рефлексологія, психологічні школи.

Постановка проблеми. Кінець продемонструвала, що існує кілька шляхів поXIX ст. ознаменувався дискусіями про те, якими шляхами будувати нову, об'єктивну психологію, які методи повинні стати провідними при дослідженні психічного. На межі століть ще здавалося, що ці суперечності приведуть до єдиної думки й сформується методологія нової, позитивної психології. Загальною тенденцією був перехід від психології, що вивчає феномени свідомості, до психології, яка досліджує цілісну систему організм-середовище.

будови такої психології, які кардинально відрізняються один від одного не тільки в розумінні пріоритетів й задач психологічної науки, але навіть у визначенні іï предмету й змісту психіки. Різним був й підхід до динаміки психічного розвитку, його закономірностей й умов, що сприяють чи перешкоджають йому.

Вплив поглядів Маха на розвиток перших психологічних шкіл сприяло розвитку «махізму» як парадигмальної основи у відноОднак логіка розвитку перших шкіл шенні до проблеми психіки загалом. Е. Мax, 
ISSN 2414-004X (Online)

розробляючи свою концепцію в руслі основних положень позитивізму, відстоював принцип емпіричної доказовості теоретичних положень [6].

Про необхідність перегляду психологічних постулатів свідчили і запити практики, які не могли ігноруватися ученими. Орієнтація на практику виражалась не тільки у філософії прагматизму, особливо популярної в США, але й у розробці міжпредметних питань, насамперед разом із медициною і педагогікою. Якщо клінічні дані у великій мірі вплинули на французьку психологію (про що говорилося вище) і на формування глибинної психології, то задачі вивчення й виховання «нової людини», розробка нових підходів до проблем соціалізації стали провідними в США i Росії, вплинувши на розвиток біхевіоризму i радянської психології $[10 ; 11]$.

Вихід 3 методологічної кризи полягав у трансформації методу, який перетворювався в опосередкований або в такій зміні предмету, що зробило би реальним його безпосереднє експериментальне вивчення (наприклад, зробити предметом зовнішню активність), або у відмові від спроб пояснити закони психіки» замінивши їх описом явищ, як свого часу пропонував Дільтей.

На зміст й динаміку протікання методологічної кризи в психології вплинули крім логіки становлення самої науки й інші фактори - соціальна ситуація, відкриття в інших дисциплінах [1].

На жаль, на сьогодні психологія не ви- йшла 3 «фази відкритої психологічної кризи», суспільно-історична ситуація та відсутність загальноприйнятого методологічного апарату відштовхує теоретичну основу психологічної науки до регресії [9].

Досягнення фізиків, які допомогли психологам по-новому побачити можливості експерименту, розкрили перспективи вивчення пізнавальних процесів. Закони й методи дослідження фізичного поля намагались застосувати при аналізі психічного поля, динаміки сприйняття й мислення гештальтпсихологи. Але, на сьогодні психологічна наука потребує більш детального дослідження. Різноманіття наукових інтересів, методологічні принципи і соціальна ситуація, у якій діяли вчені першої третини XX ст., не дозволяли прийти до загального розуміння цілей, предмета психології та її методів.

\section{Аналіз останніх досліджень і публіка-}

цій. Проблемою методології та дослідження періоду «відкритої психологічної кризи» займались науковці та дослідники, такі як: Е. Max, Е. Гуссерль, А. Бергсон наполягаючи на перегляді методологічних основ, відстоюючи принципи емпіричної доказовості теоретичних положень. С. Л. Рубінштейн, Л. С. Виготський, $\quad$ В. А Роменець порушуючи культурно-історичний аспект та досліджуючи особливості перебігу психологічної кризи, зокрема, особливу увагу приділяючи вчинковому підходу (В. А. Роменець). М. Г. Ярошевський та його послідовники порушуючи питання принципів історико-психологічного дослі- 
дження наполягали на чіткому їх дотриманні. Здійснений аналіз досліджень та публікацій дозволяє нам підійти до виділення невирішених частин окресленої проблеми $[11 ; 14 ; 15$; 22].

\section{Виділення невирішених раніше час-} тин загальної проблеми. Проблема виникнення та розвитку періоду «відкритої психологічної кризи» вказує на проблему методологічного, фундаментального та практичного (прикладного) змісту, наслідком якої психологічна наука отримала поштовх до створення наукових психологічних шкіл (психоаналіз, біхевіоризм, гештальтпсихологія, гуманістична психологія). Однак, ідейні вподобання дослідників кожного з напрямів призводили до непорозумінь та конфліктів, що негативно позначалось на дослідженнях психіки загалом, беручи за уваги, фрагментарну теоретичну основу не виходячи з розуміння власних концепцій та переконань [17].

Таким чином, фактично вже до 20-х років XX рр., психологія розділилася на окремі школи, які по-різному формували свої концепції про зміст та структуру психіки, розглядаючи в якості провідної пізнавальну, мотиваційну, поведінкову сфери психічного. На початку XX століття з'явилися три провідні напрямки - біхевіоризм, гештальтпсихологія i глибинна психологія, кожний з яких мав власний предмет психології і свій метод дослідження психіки [22].

Предметом біхевіоризму стала поведін- ка, яка досліджувалась шляхом експериментального вивчення факторів, що впливають на їі формування, тобто на утворення зв'язків між стимулами і реакціями. Гештальтпсихологія предметом дослідження ставила цілі структури, 3 яких складається психічне поле (передусім «поле свідомості»), причому для вивчення цих гештальтів застосовувалися нові методи, які розроблялися за аналогією з методами вивчення фізичного поля. Глибинна психологія зробила своїм предметом глибинні, безсвідомі структури психіки, методом вивчення яких став психоаналіз. Пізніше, вже в другій половині XX в., виникли нові школи гуманістична й когнітивна психологія [6]

Як видно з наведеного огляду, ні предмети, ні методи у вище зазначених школах зовсім не співпадали між собою, а тому на перших етапах становлення психологічних шкіл неможливо було й говорити про певне об‘єднання. Пройшло кілька десятиліть самостійного розвитку, відповідно, за цей час було накопичено багато нових фактів кожним з напрямків, перш ніж стало можливим знову вести мову про об'єднання, у створенні єдиної психології [1;2].

Формулювання мети. Після грунтовних теоретичних досліджень ми формуємо нову парадигму, застосовуючи культурноісторичне надбання психологів, які особливу увагу приділяли періоду «відкритої психологічної кризи». Метою проблемного викладу та аналізу характеристики історико- 
психологічного процесу постає врахування принципів дослідження (детермінізму, розвитку, свідомості та діяльності), беручи за основу концептуальні погляди С. Л. Рубінштейна [15; $18]$.

На думку С. Л. Рубінштейна, «вирішальну роль у становленні психології як самостійної науки відіграло запровадження експерименту, що «не тільки озброїло ії̈ новим для неї, дуже потужним методом наукового мислення, а й взагалі по-новому поставило питання про методику психологічного дослідження в цілому, висунувши нові вимоги i критерії науковості всіх видів досвідченого дослідження в психології» [16].

Виникнення загальної психології як самостійної та фундаментальної галузі психологічної науки пов'язане 3 ім'ям С. Л. Рубінштейна, який систематизував психологічні знання і запропонував методологію дослідження психічних явищ. На базі основних понять загальної психології формуються поняття та інших галузей психологічної науки.

Виклад основного матеріалу дослідження. С. Л. Рубінштейн запропонував своєрідну характеристику історикопсихологічного процесу. Вчений здійснив кілька грунтовних спроб дослідження цього предмета, насамперед у працях «Основи загальної психології» (1946), «Принципи і шляхи розвитку психології» $(1959)$ [17; 18].

Вчений звернув особливу увагу на тему «кризи» психології, пов'язаної з формуванням поведінкової психології - рефлексології та біхевіоризму, напрямів, що заперечували свідомість як предмет психології, а саму діяльність тлумачили механістично.

Задовго до західних істориків психології С. Л. Рубінштейн показав історикопсихологічну тріаду: поведінкознавство (біхевіоризм), психоаналіз, гуманістична психологія. Він заперечував спроби побудувати психологію на «культурних» засадах, а також біологічних, що призведе до втрати науковості концептуального викладу [15].

У руслі створення «системи радянської психології» С. Л. Рубінштейн намагався сформулювати іiі методологічні засади, у зв'язку 3 чим проголошував ідею єдності свідомості та діяльності. Всі проблеми теорії та історії психології зосереджуються ним в єдиному вчинковому принципі, за допомогою якого вирішується центральна проблема психології - проблема людини.

Рубінштейн прогнозував появу зв'язків психології з етикою, що феноменологічно наповнює істинним змістом психологічне дослідження. В історії психології вчений наголошував на необхідності подолання двох тенденцій - дуалістичного відособлення психічно-суб'єктивного від процесів тілесних (протиставлення душі й тіла) та зняття дуалізму зведенням тілесних явищ до душевних проявів або душевних до тілесних («бездійова свідомість» та «несвідома дійєвість»). Рубін- 
штейн виступав проти відриву душевного від тілесного та проти їх ототожнення, відшукуючи психологічний детермінізм та його постання в історії психологічних учень [16].

В загальних рисах, радянська психологія задавала тон філософії, створюючи в значній мірі, напротивагу фізиці та іншим точним і загальним природничим наукам. Перші ідеологічні дискусії в СРСР, пов'язані з питаннями природознавства відображались саме на психологічному фронті (матеріали Першого Психоневрологічного з’їзду в Москві в 1923 р.). В психології концентрувались найважливіші проблеми того часу, виховання нової людини як індивідуальності та виховання колективів [12; 19].

Як наслідок, така ситуація оцінювалася вченими як криза психології. I з такою оцінкою важко не погодитися, якщо вважати цю закономірну методологічну кризу кризою становлення психологічної науки. Природно, що розвиток неможливий без пошуків нового, без помилок взагалі. Сучасна психологія розвитку довела, що кожен критичний період починається з негативізму, заперечення, який змінюється періодом розвитку. А психологія справді змінювалась, ставала все більш значимою і для суспільства, і для інших наук [4].

Не дивно, що такі кардинальні зміни були пов'язані із питанням негативізму по відношенню до старої психології, пошуковою активністю при формуванні нової науки, появі нових відкриттів і нових напрямків у пси- хології. Однак вчені початку століття, ще прагнули прийти до спільної думки про єдину психологію, відчували кризу як неможливість iï подолати, тобто як розпад старої психологічної науки, що було справедливо, і як безвихідь в процесі становлення нової, що, як доведено часом, було невірно.

Цим пояснюється і той парадоксальний на перший погляд факт, що період, котрий ми зараз оцінюємо як час розквіту наукової творчості видатних вчених, період, що визначив розвиток психологічної науки XX ст., усвідомлювався вченими як занепад, як «відкрита криза».

Не дивно, що такі кардинальні зміни були пов'язані із питанням негативізму по відношенню до старої психології, пошуковою активністю при формуванні нової науки, появі нових відкриттів і нових напрямків у психології.

Таким чином, фактично вже до 20-х років XX рр., психологія розділилася на окремі школи, які по-різному формували свої концепції про зміст та структуру психіки, розглядаючи в якості провідної пізнавальну, мотиваційну, поведінкову сфери психічного. На початку XX століття з'явилися три провідні напрямки - біхевіоризм, гештальтпсихологія i глибинна психологія, кожний з яких мав власний предмет психології і свій метод дослідження психіки $[19 ; 20]$.

Предметом біхевіоризму стала поведінка, яка досліджувалась шляхом експеримен- 
тального вивчення факторів, що впливають на iii формування, тобто на утворення зв'язків між стимулами і реакціями. Гештальтпсихологія предметом дослідження ставила цілі структури, 3 яких складається психічне поле (передусім «поле свідомості»), причому для вивчення цих гештальтів застосовувалися нові методи, які розроблялися за аналогією 3 методами вивчення фізичного поля. Глибинна психологія зробила своїм предметом глибинні, безсвідомі структури психіки, методом вивчення яких став психоаналіз. Пізніше, вже в другій половині XX в., виникли нові школи гуманістична й когнітивна психологія.

Як видно з наведеного огляду, ні предмети, ні методи у вище зазначених школах зовсім не співпадали між собою, а тому на перших етапах становлення психологічних шкіл неможливо було й говорити про певне об‘єднання. Пройшло кілька десятиліть самостійного розвитку, відповідно, за цей час було накопичено багато нових фактів кожним з напрямків, перш ніж стало можливим знову вести мову про об'єднання, у створенні єдиної психології. Різні позитивні зрушення в дослідженні історико-психологічних проблем припадають на XX століття, особливо на його другу половину, якщо в останній чверті XIX наполегливо підбивали підсумки століття в цілому, то в XX столітті - підсумки тисячоліть [7].

Криза у психології, характеризується, двома рисами: по-перше, загальною незадово- леністю застарілою методологічною системою, яка може бути названа, взагалі асоціаністичною та сенсуалістичною психологією, i, по-друге, появою значної кількості нових спроб поглибити сенс (смисл) психологічних досліджень (Ланге, 1996, с.69).

M.M. Ланге визначив ознаки періоду відкритої кризи в історії психології: критерій «величезної розбіжності» («відсутність загальноприйнятої системи в науці») - якщо він існує, то психологія не має «основи», «фундаменту», позиції по відношенню до яких методи дослідження, якими оперує більшість психологів повинні збігатися [8].

Питання методології дослідження змушували замислюватись велику кількість науковців. Традиційна для психології велика кількість шкіл і підходів до вивчення тієї чи іншої конкретної проблеми стимулювало звернення уваги на власне методологічні питання науки.

У двадцяті роки XX століття склалася ситуація, яка сприяла розробці методологічних проблем. Безсумнівний факт кризового стану змусив психологів багаторазово аналізувати його найближчі причини, його джерела та рушійні сили, чинники, що ускладнюють його розвиток в радянських умовах. Все це стимулювало інтерес до виявлення підстав психології. Гостре відчуття необхідності побудови нової психології (всі автори, які писали про кризу, були напрочуд одностайні в одному - вони стверджували, що нова психологія ще тільки має народитися) 
сприяло формуванню уявлення про те, що можуть бути виявлені і описані закономірності формування психологічної теорії [11].

Смисл періоду «відкритої психологічної кризи» полягає у багатоманітності дихотомічних уявлень вчених стосовно тлумачення i розгляду предмету історикопсихологічних досліджень - психіки у всій іiі різноманітності. Дослідження «ролі» постає науковою проблемою в дослідженні цього складного і водночас надзвичайно цікавого періоду психологічної науки «відкритої психологічної кризи».

Висновки. Після грунтовного теоретико-методологічного аналізу ми вивели загальне поняття періоду «відкритої психологічної кризи».

Період «відкритої психологічної кризи» - історичний період (1910-1930рр.) обумовлений невідповідністю сформованих психологічних уявлень та потребою суспільства у розвитку нових досліджень в психологічній науці і практиці. Таким чином невідповідність застарілої системи методології зумовила потребу у створенні нового наукового (понятійно-категоріального) апарату [9].

Наше історико-психологічне дослідження грунтуються на основі методологічних принципів об’єктивності дослідження, багатомірного та багаторівневого існування предмета, дослідження явищ історії психології у їх розвитку, єдності історичного та логічного, пізнання у формі спіралі, боротьби ма- теріалізму та ідеалізму.

Розвиток психологічної науки значною мірою визначається тим, наскільки правильно, всебічно і глибоко розоблені їі теоретичні основи. Будь-яке відставання науки в цьому відношенні $з$ необхідністю веде до іiі відставання в розгортанні конкретного наукового дослідження, зниження його наукового рівня та практичної цінності.

\section{Перелік використаних джерел:}

1. Асмолов А. Г. Культурно-историческая психология и конструирование миров / А. Г. Асмолов. - Минск: Воронеж, 1996. - 309 с. - (7-e).

2. Бехтерев В. М. Общие основы рефлексологии человека. / В. М. Бехтерев. - Л: Госиздат, 1996. - 598 с. (10).

3. Бехтерев B. М. Субъективный и объективный метод в изучении личности / В. М. Бехтерев. // 11. - 2013. C. $34-54$.

4. Выготский Л. С. Исторический смысл психологического кризиса / Л. С. Выготский. // 3-е. - 2008. - №1. C. $56-65$.

5. Выготский Л. С. Психология / Л. С. Выготский. Москва: Изд-во ЭКСМО-Пресс, 2000. - 312 с. - (2). (Мир психологии).

6. История зарубежной психологии, 30-е - 60-е гг. ХХ в.: Тексты / Под ред. П.Я. Гальперина. - М.: Изд-во МГУ, 1986. - 344 с.

7. Ланге Н. Н. Психология / Н. Н. Ланге. // Мир. 2014. - №6. - C. 10-34.

8. Ланге Н. Н. Психология / Н. Н. Ланге. // 8. - 2014. №12. - C. 56-98.

9. Ларін Д. І. Теорія вчинку, її місце у вітчизняній та зарубіжній психології. Вчинкова психологія: історія та сучасність: матеріали міждисциплінарного круглого столу з нагоди 90-річчя професора В.А. Роменця, 20 
травня 2016 року / За ред. І.В. Данилюка. - К.: Логос, 2016. C 17-19.

10. Лейбниц Г. В. Избр. филос. соч / Г. В. Лейбниц. Москва: Монадология, 1990. - 346 с. - (2-е дополненое).

11.Ломов Б. Ф. Методологические и теоретические проблемы психологии / Б. Ф. Ломов. - Москва: Соцекгиз, 2004. - 468 с. - (3-е изд., испр. и доп.). (Мировая философия; 4).

12. Павлов И. П. Условный рефлекс / И. П. Павлов // Двадцатилетний опыт исследования Высшей нервной деятельности (поведения) животных / И. П. Павлов. Москва: Астрель, 2010. - (Научное пособие). - (Наука; 5). - C. 168-179.

13. Роменець B. A. Історія психологія XIX - початку XX століття / В. А. Роменець. - Київ: Вища школа, 2005. $613 \mathrm{c}$.

14. Роменець В. А. Історія психології ХХ століття / В.

А. Роменець, І. П. Маноха. - Київ: Либідь, 1998. - 988 c.

15. Рубинштейн С. Л. Проблемы общей психологии / С. Л. Рубинштейн. - Москва: Азбука-классика, 2003. $589 \mathrm{c.}$

16. Рубинштейн С. Л. Основы общей психологии / С. Л. Рубинштейн. - Санкт-Петербург: Питер, 1999. - 609 c.

17. Рубинштейн С. Л. Культурно-историческое становление личности / С. Л. Рубинштейн // Основы общей психологии / С. Л. Рубинштейн. - Москва: Акад. педагог. Наук РСФР, 2009. - (3-е изд., испр. и доп.). (Академкнига). - С. 208-233.

18. Рубинштейн С. Л. Основы онтологии, логики и психологии / С. Л. Рубинштейн // Избранные труды / С. Л. Рубинштейн. - Москва: Наука, 1997. - (2-е дополненое). - (Психология; 2). - С. 405-453.

19. Уотсон Д. Психология как наука о поведении / Дж Уотсон. - Москва: Госиздат, 1996. - 440 с.

20. Уотсон Д. Бихевиоризм / Дж Уотсон. // История психологии (10-е - 30-е гг. Период открытого кризиса) Тексты. 2-е изд. / Под ред. П.Я. Гальперина, А. Н.
Ждан.. - 1992. - №2. - С. 56-89.

21. Ярошевский М. Г. История психологии / М. Г. Ярошевский - М.: Мысль, 1985. - 575 с.

22. Ярошевский М. Г. Философско-психологичесские воззрения А. А. Потебни / М. Г. Ярошевский // Известия АН СССР, серия истории и философии, №2, т. III, 1946.

\section{References (Transliteration):}

1. Asmolov A. G. Kul'turno-istoricheskaya psihologiya i konstruirovanie mirov / A. G. Asmolov. - Minsk: Voronezh, 1996. - 309 s.

2. Bekhterev $V . \quad M$. Obshchie osnovy refleksologii cheloveka. / V. M. Bekhterev. - L: Gosizdat, 1996. - 598 s. 3.Bekhterev V. M. Sub"ektivnyj i ob"ektivnyj metod v izuchenii lichnosti / V. M. Bekhterev. // 11. - 2013. - S. 34 -54 .

4. Vygotskij L. S. Istoricheskij smysl psihologicheskogo krizisa / L. S. Vygotskij. // 3-e. - 2008. - №1. - S. 56-65.

5. Vygotskij L. S. Psihologiya / L. S. Vygotskij. - Moskva: Izd-vo EHKSMO-Press, 2000. - 312 s. - (2). - (Mir psihologii).

6. Istoriya zarubezhnoj psihologii, 30-e - 60-e gg. HKH v.: Teksty / Pod red. P.YA. Gal'perina. - M.: Izd-vo MGU, 1986. - $344 \mathrm{~s}$.

7. Lange N. N. Psihologiya / N. N. Lange. // Mir. - 2014. №6. - S. 10-34.

8. Lange N. N. Psihologiya / N. N. Lange. // 8. - 2014. №12. - S. 56-98.

9. Larin D. I. Teoriya vchy`nku, yiyi misce u vitchy`znyanij ta zarubizhnij psy`xologiyi. Vchy`nkova psy`xologiya: istoriya ta suchasnist': materialy` mizhdy`scy`plinarnogo kruglogo stolu z nagody` 90richchya profesora V.A. Romencya, 20 travnya 2016 roku / Za red. I.V. Dany'lyuka. - K.: Logos, 2016. S 17-19.

10. Lejbnic G. V. Izbr. filos. soch / G. V. Lejbnic. Moskva: Monadologiya, 1990. - 346 s. - (2-e dopolnenoe). 11. Lomov B. F. Metodologicheskie i teoreticheskie problemy psihologii / B. F. Lomov. - Moskva: Socekgiz, 
2004. - 468 s. - (3-e izd., ispr. i dop.). - (Mirovaya filosofiya; 4).

12. Pavlov I. P. Uslovnyj refleks / I. P. Pavlov // Dvadcatiletnij opyt issledovaniya Vysshej nervnoj deyatel'nosti (povedeniya) zhivotnyh / I. P. Pavlov. - Moskva: Astrel', 2010. - (Nauchnoe posobie). - (Nauka; 5). - S. 168 -179 .

13. Romenecz V. A. Istoriya psyhologiyi XX stolittya / V. A. Romenecz’, I. P. Manoxa. - Ky`yiv: Ly`bid’, 1998. $988 \mathrm{~s}$.

14. Ruby 'nshtejn S. L. Problemы obshhej psy`xology`y` / S.

L. Ruby`nshtejn. - Moskva: Azbuka-klassy`ka, 2003. - 589 $\mathrm{S}$.

15. Rubinshtejn S. L. Problemy obshchej psihologii / S. L. Rubinshtejn. - Moskva: Azbuka-klassika, 2003. - 589 s.

16. Rubinshtejn S. L. Osnovy obshchej psihologii / S. L. Rubinshtejn. - Sankt-Peterburg: Piter, 1999. - 609 s.

17. Rubinshtejn S. L. Kul'turno-istoricheskoe stanovlenie lichnosti / S. L. Rubinshtejn // Osnovy obshchej psihologii / S. L. Rubinshtejn. - Moskva: Akad. pedagog. Nauk RSFR, 2009. - (3-e izd., ispr. i dop.). - (Akademkniga). - S. 208233.

18. Rubinshtejn S. L. Osnovy ontologii, logiki i psihologii /

S. L. Rubinshtejn // Izbrannye trudy / S. L. Rubinshtejn. Moskva: Nauka, 1997. - (2-e dopolnenoe). - (Psihologiya; 2). - S. 405-453.

19. Uotson D. Psihologiya kak nauka o povedenii / Dzh Uotson. - Moskva: Gosizdat, 1996. - 440 s. - (3-e izd., ispr. i dop.). - (Aktual'naya psihologiya; 4).

20. Uotson D. Biheviorizm / Dzh Uotson. // Istoriya psihologii (10-e - 30-e gg. Period otkrytogo krizisa) Teksty. 2-e izd. / Pod red. P.YA. Gal'perina, A. N. ZHdan.. - 1992. - №2. - S. 56-89.

21. Yaroshevskij M. G. Istoriya psihologii / M. G. YAroshevskij - M.: Mysl', 1985. - 575 s.

22. Yaroshevskij M. G. Filosofsko-psihologichesskie vozzreniya A. A. Potebni / M. G. YAroshevskij // Izvestiya AN SSSR, seriya istorii i filosofii, №2, t. III, 1946.

\section{Larin Dmitro}

PhD student at department of psychology at Taras Shevchenko National University of Kyiv, Kyiv (Ukraine)

\section{DESCRIPTION HISTORICAL AND PSYCHOLOGICAL PROCESS IN THE CONTEXT OF «OPEN PSYCHOLOGICAL CRISIS» IN THE VIWS OF S. RUBINSTEIN}

\section{ABSTRACT}

This article characteristic historians psychological process in the context of the period of «open psychological crisis» according to the conceptual approach of the outstanding scientist, Sergey Leonidovich Rubinstein. Described methodological principles and their significance for historical and psychological sciences, outlined the problems of psychological schools first third of the XX century.

Special attention is drawn to the formation of behavioral psychology - behaviorism and reflexology. All the problems of theory and history of psychology S. L. Rubinstein focused on a single principle by which solved the central problem of psychology - the problem of man.

On the need to review the psychological tenets and demands testified practices that could not be ignored by scientists. Orientation to practice expressed not only in the philosophy of pragmatism, especially popular in the US but also in the development of interdisciplinary issues, especially along with medicine and pedagogy. If clinical data is heavily influenced by the French psychology (as mentioned above) and on the formation of depth psychology, the task of studying 
and education of the «new man», the development of new approaches to socialization were leading in the United States and Russia, affecting the development of behaviorism and Soviet psychology.

Our historical and psychological studies are based on the principles of objectivity on methodological research, multi-dimensional and multi-existence of the subject, the study of phenomena in the history of psychology of development, unity and historical logic, knowledge in the form of a spiral, fighting materialism and idealism.

The development of psychological science is largely determined by how correctly and comprehensively and deeply researched its theoretical foundations. Any backlog of science in this respect is the need for its lag in the deployment of specific research, reducing its level of scientific and practical value.

Keywords: historical and psychological process, «open psychological crisis» methodology, principles, theories, behaviorism, reflexology, psychological school.

\section{Ларин Дмитрий Игоревич}

Аспирант кафедры общей психологии, Киевского наџионального университета имени Тараса Шевченко, г. Киев (Украина)

ХАРАКТЕРИСТИКА ИСТОРИКОПСИХОЛОГИЧЕСКОГО ПРОЦЕССА В КОНТЕКСТЕ ТЕЧЕНИЯ «ОТКРЫТОГО ПСИХОЛОГИЧЕСКОГО КРИЗИСА» ВО ВЗГЛЯДАХ С. Л. РУБИНШТЕЙНА

Аннотация. В данной статье представ- лена

характеристика

историко-

психологического процесса в контексте периода «открытого психологического кризиса» согласно концептуального подхода выдающегося ученого, Рубинштейна Сергея Леонидовича. Описаны методологические принципы и их значение для историко-психологической науки, определено проблематика развития психологических школ первой трети $\mathrm{XX}$ века.

Особое внимание автор обращает на формирование поведенческой психологии рефлексологии и бихевиоризма. Все проблемы теории и истории психологии сосредотачиваются С. Л. Рубинштейном в едином поступковом принципе, с помощью которого решается центральная проблема психологии проблема человека.

\section{Ключевые слова: историко-} психологический процесс, «открытый психологический кризис», методология, принципы, теории, бихевиоризм, рефлексология, психологические школы.
Дата отримання статті: 15.04 .2017 Дата рекомендації до друку: 20.04.2017 